\title{
Major Soil Classes of the Metropolitan Region of Curitiba (PR), Brazil: I - Mineralogical Characterization of the Sand, Silt and Clay Fractions
}

\author{
Ana Christina Duarte Pires ${ }^{1}$, Vander de Freitas Melo ${ }^{2 *}$, Valmiqui Costa Lima ${ }^{2}$ and \\ Antônio Carlos Vargas Motta ${ }^{2}$ \\ ${ }^{1}$ Curso de Pós-Graduação em Ciência do Solo; Universidade Federal do Paraná; ${ }^{2}$ Departamento de Solos e \\ Engenharia Agrícola; Rua dos Funcionários, 1540; vanderfm@ufpr.br; 80035-050; Curitiba-PR-Brasil
}

\begin{abstract}
The aim of this work was to evaluate the mineralogical and chemical characteristics of most representative soils of the Region of Curitiba, Paraná State. Samples were collected at different depths. The results showed: (a) the quartz was the only identified mineral at the silt and sand fractions. The dominant clay mineral was Kaolinite, with contents ranging from 676.7 to $820.8 \mathrm{~g} \mathrm{~kg}^{-1}$. The gibbsite was also an important constituent of the most weathered horizons and the hematite and goethite contents were low, mainly in the Histosol; $(b)$ at the C horizon of the Inceptisol, high intensity of vermiculite/smectite reflections were detected (X-ray diffraction), justifying the high capacity of expansion and contraction, normally showed for this soil horizon; (c) was observed a good relation between pedogenetic degree and crystallographic mineral characteristics.
\end{abstract}

Key words: Kaolinite, crystalline and amorphous Fe and Al oxides, 2:1 minerals, XRD

\section{INTRODUCTION}

The soil is a product of five factors (parent material, clime, landscape, time and organism) and four processes (addition, removal, translocation and transformation). As a result, is observed a big soil diversity in the landscape with morphological, physical, chemical and mineralogical distinct characteristics. Due to these characteristics, the pronounced effects of the granulometry and mineralogy of the soils of the urban regions at the planning and impact of the antropic activities has been shown.

The necessities and the problems due to the fast population growth of Curitiba and Metropolitan Region has to the development of studies about geology and soil characteristics, which could provide subsidies for the engineering works, urban planning and environmental questions (Kormann et al., 1999). The geological formation of this region comes from the Quaternary Period, formed by fluvial sediments, called Guabirotuba Formation (Bigarella and Salamuni, 1962). This formation consists of less consolidated sediments, constituted by claystones and sandstones (Salamuni and Stellfeld, 2001). In the soils under dominion of the Guabirotuba Formation, the clayey texture prevails, with the expansive clays presence, but with contributions of the silte and sandy fractions (Santos, 2002). The mineralogical data available about the Guabirotuba Claystone Formation indicated that there was the

\footnotetext{
${ }^{*}$ Author for correspondence
} 
predominance of the smectite group, possibly montmorilonite (Massad et al., 1981). However, the soil profile presented characteristics preferably associated with the kaolinite (Boszczowski, 2001). The secondary 2:1 minerals have an octhaedral sheet that shares oxygen atoms between two tetrahedral sheets. The principal examples of this class of mineral are, with more occurrence in the soils, vermiculite and montmorilonite (smectite) (Schulze, 1989). Within this group of minerals the distinction between expansive (montmorilonite), limited expansibility (vermiculite) and nonexpansive (illite and hydroxy-interlayered vermiculite - HIV) must be considered. The vermiculite presents most part of the isomorphic substitution at the tetrahedral sheets $\left(\mathrm{Si}^{4+}\right.$ by $\left.\mathrm{Al}^{3+}\right)$, resulting into a high structural charge and high cation exchange capacity (CEC), where the average value is around $150 \mathrm{cmol}_{\mathrm{c}} \mathrm{kg}^{-1}$ (Douglas, 1989). The high structural charge results into a high adsorption energy of hydrated cations among $2: 1$ units, maintaining the units together; for this reason its expansively is considered limited. On the other hand, the montmorilonite (smectite) presents isomorphic substitution, preferably at the octahedral sheets $\left(\mathrm{Al}^{3+}\right.$ by $\left.\mathrm{Mg}^{2+}\right)$, responsible by the CEC average value of $100 \mathrm{cmol}_{\mathrm{c}} \mathrm{kg}^{-1}$ (Borchardt, 1989). Due to the smallest quantity of charge and the farthest distance of the structural charges, the water molecules and the intercalated cations cause the expansion of the mineral. As a result of the smectite high activity, the subsuperficial horizons of the soils developed from claystone of the Guabirotuba Formation present expansion and contraction characteristics, which ones must be observed, for example, at the engineering works.

The kaolinite $(\mathrm{Kt})$ is the most important mineral of the groups of the 1:1 phylosillicate minerals, and is considered the major mineral of the soils developed under humid tropical conditions (Singh and Gilkes, 1992). The $\mathrm{Kt}$ is composed of a tetrahedral and an octahedral sheets, which constitute a single $0.7 \mathrm{~nm}$ layer in a triclinic unit cell. Two-thirds of the octahedral positions are occupied by $\mathrm{Al}$ ions, and the tetrahedral positions are occupied by $\mathrm{Si}$ ions. The surface $\mathrm{OH}^{\prime}$ s bond through their $\mathrm{H}$ 's to the $\mathrm{O}$ plane of adjacent layer (Grim, 1968). Consequently, expansion does not occur and there is no access of cations and water between the layers. As a result of very little or no isomorphic substitution, its CEC is $\mathrm{pH}$ dependent, where the average value is $10 \mathrm{cmol}_{\mathrm{c}} \mathrm{kg}^{-1}$ (McBride,
1994). This way, its specific area gets restricted to external surfaces, what, allied to the little charge of the mineral, results into a reduced CEC.

The Fe (hematite and goethite) and $\mathrm{Al}$ (gibbsite) oxides are also important constituents of the highly weathered soils of the humid tropics. Normally, these oxides determine the color and influence the structure and ionic change reactions of the soils. In addition to its effects at the physical-chemical properties of the soils, the $\mathrm{Al}$ and $\mathrm{Fe}$ oxides are indicators of pedogenetic environments (Fitzpatrick and Schwertmann, 1982).

In addition of the mineralogical composition of the clay fraction, the nature and the crystallographic characteristics of the minerals are important to define the physical-chemical behavior of the soils. Higher activity in the soil (higher capacity of adsorption, water retention, etc.) is related to minerals with higher specific surface (defined by size and form), higher density of superficial electric charges and lower crystallinity degree.

The objective of the present was to study the mineralogy of the principal classes of soils of the Metropolitan region of Curitiba, Paraná State, including the crystallographic characteristics of the minerals.

\section{MATERIALS AND METHODS}

The studied area corresponded to the metropolitan region of Curitiba, located in the South of Brazil, at the First Paranaense Plateau, between Serra do Mar (west) and Devoniana Cliff (east), belongs to hydrographic basin of Alto Iguaçu, with average altitude of $920 \mathrm{~m}$ (IPPUC, 1991). Curitiba's region clime has been classified as $\mathrm{Cfb}$ type, according to Köeppen's, defined as mesotermic humid and super humid. The annual average temperature is $16.5{ }^{\circ} \mathrm{C}$, being $20.4{ }^{\circ} \mathrm{C}$ in the hottest months and $12.7^{\circ} \mathrm{C}$ in the coldest months, with occurrence of frequent hard frost. The annual average precipitation ranges from 1,400 and $1,500 \mathrm{~mm}$ and is regularly distributed for all the months, and the air relative humidity is around $81 \%$ (Maack, 1969).

The three major soil classes of the metropolitan region of Curitiba occupied around $87.5 \%$ total area, distributed among Cambisol (60\%), Latosol (17\%) and Organosol (10.5\%) (EMBRAPA, 1984 and 1999). Representative soil for each class was selected and sampled (Table 1) on the 
Experimental Farm of Canguiri (Federal University of Paraná), located at the metropolitan region of Curitiba, in Pinhais city (PR). After the collection of soil material (Histosol $-\mathrm{H}$ horizon, Oxisol - A and B horizons and Inceptisol - A, B and $\mathrm{C}$ horizons; total of 6 samples), the samples were dried and sieved $(2 \mathrm{~mm})$ for mineralogical characterization. The particles-size was determined by pipette method (EMBRAPA,1997).

Table 1 - Granulometric analysis and soil organic carbon (soc) content for soils from metropolitan region of Curitiba - Parana State - Brazil

\begin{tabular}{lllcccccccc}
\hline \multirow{2}{*}{$\begin{array}{l}\text { Sample } \\
\text { No. }\end{array}$} & $\begin{array}{c}\text { Brazilian } \\
\text { classification }\end{array}$ & $\begin{array}{c}\text { U.S. } \\
\text { Taxonomy }\end{array}$ & Horizon & $\begin{array}{c}\text { Sampling } \\
\text { depth }\end{array}$ & SOC $^{2}$ & Clay & Silt & $\begin{array}{c}\text { Fine } \\
\text { Sandy }\end{array}$ & $\begin{array}{c}\text { Coarse } \\
\text { sandy }\end{array}$ & $\begin{array}{c}\text { Total } \\
\text { sandy }\end{array}$ \\
\hline & & & & $\mathrm{cm}$ & $\mathrm{g} \mathrm{dm}^{-3}$ & & & $\mathrm{~g} \mathrm{~kg}^{-1}$ & \\
\hline 1 & Organosol & Histosol & $\mathrm{H}$ & $0-60$ & 93.6 & 669 & 252 & 61 & 19 & 79 \\
2 & Latosol & Oxisol & $\mathrm{A}$ & $0-30$ & 27.5 & 457 & 221 & 161 & 161 & 322 \\
3 & Latosol & Oxisol & $\mathrm{Bw}$ & $30-220$ & 5.7 & 604 & 174 & 116 & 106 & 222 \\
4 & Cambisol & Inceptisol & $\mathrm{A}$ & $0-34$ & 35.3 & 602 & 90 & 213 & 95 & 308 \\
5 & Cambisol & Inceptisol & $\mathrm{Bi}$ & $34-99$ & 8.8 & 488 & 257 & 198 & 57 & 255 \\
6 & Cambisol & Inceptisol & $\mathrm{C}$ & $99-200$ & 3.9 & 356 & 418 & 208 & 19 & 226 \\
\hline
\end{tabular}

${ }^{1}$ Approximate correlation with U.S. Soil Taxonomy.

${ }^{2}$ Soil Organic Carbon (Pavan et al., 1992).

The soil samples were treated with sodium hypochlorite for organic matter removal and with $0,2 \mathrm{~mol} \mathrm{~L}^{-1} \mathrm{NaOH}$ for particles dispersion (Jackson, 1979). After these treatments, the sand fraction was retained in a sieve of $0.05 \mathrm{~mm}$ and the clay and silt fractions were separated by sedimentation, based on the Stokes law (Gee and Bauder, 1986). Random samples of sand, silt and clay fractions were built up for the minerals identification by X-rays diffraction (XRD). The diffractograms were obtained in a computer controlled Philips PW 1050/70 vertical goniometry, with a angular speed of $1^{\circ} 2 \theta \mathrm{min}^{-1}$ and horizontal scale ranging from 4 to $65^{\circ} 2 \theta$. The diffractometer, equipped with $\mathrm{Ni}$ filter and using $\mathrm{CuK} \alpha$ radiation, was operated at $20 \mathrm{~mA}$ and 40 $\mathrm{kV}$. Additional treatments were made to differentiate the 2:1 secondary minerals of the clay fraction (Whittig and Allardice, 1986): saturation with $\mathrm{Mg}$ and glycerol, with $\mathrm{K}$ and dryness at 550 ${ }^{\circ} \mathrm{C}$ in muffle. After the treatments, the samples were built up in glass slat (parallel-oriented samples), and analyzed by XRD, at an horizontal scale ranging from 3 to $15^{\circ} 2 \theta$.

To determine the amorphous $\mathrm{Fe}$ and $\mathrm{Al}$ oxides and crystalline $\mathrm{Fe}$ oxides contents and chemical composition, clay fraction was submitted to extractions with $0,2 \mathrm{~mol} \mathrm{~L}^{-1}$ ammonium oxalate, $\mathrm{pH} 3,0$ (AO) (McKeague, 1978) and dithionitecitrate-bicarbonate (DCB) (Mehra and Jackson, 1960), respectively (Melo et al., 2001b). The Fe and $\mathrm{Al}$ contents were determined by atomic absorption spectrophotometry. After the attack by $\mathrm{AO}$, the remained solid was washed with solution of $1 \mathrm{~mol} \mathrm{~L}^{-1}\left(\mathrm{NH}_{4}\right)_{2} \mathrm{CO}_{3}$ and deionized water to remove of salt excess. Then, the remained solid was dried at $105{ }^{\circ} \mathrm{C}$ for $12 \mathrm{~h}$ and weighted in order to obtain the amorphous $\mathrm{Al}$ and $\mathrm{Fe}$ oxides contents by weight reduction with the treatment.

In addition, the crystalline Fe oxides (goethite - Gt and hematite $-\mathrm{Hm}$ ) were studied by XRD in the clay fractions concentrated samples, by the kaolinite $(\mathrm{Kt})$ and gibbsite $(\mathrm{Gb})$ removal through the extraction with boiling $5 \mathrm{~mol} \mathrm{~L}^{-1} \mathrm{NaOH}$, for a period of $1.5 \mathrm{~h}$ in sand bath at $250{ }^{\circ} \mathrm{C}$ (Norrish and Taylor, 1961). To avoid dissolution of $\mathrm{Fe}$ oxides with high isomorphic substitution of $\mathrm{Fe}$ by $\mathrm{Al}$ (Kämpf and Schwertmann, 1982), penta-hydrated sodium meta-silicate $\left(\mathrm{Na}_{2} \mathrm{SiO}_{3} 5 \mathrm{H}_{2} \mathrm{O}\right)$ was added, in a $\mathrm{NaOH}$ solution (final concentration of $0.2 \mathrm{~mol}$ $\left.\mathrm{L}^{-1} \mathrm{Si}\right)$. The residual sodalite $\left[\mathrm{Na}_{4} \mathrm{Al}_{3} \mathrm{Si}_{3} \mathrm{O}_{12}(\mathrm{OH})\right]$, formed during $\mathrm{NaOH}$ treatment, was removed by two successive extractions with $0.5 \mathrm{~mol} \mathrm{~L}^{-1} \mathrm{HCl}$ (Singh and Gilkes, 1991).

After washing to remove the salt excess, the $5 \mathrm{~mol}$ $\mathrm{L}^{-1} \mathrm{NaOH}$ residue was analyzed by XRD (random sample) at an amplitude from 10 a $40{ }^{\circ} 2 \theta$ and goniometer speed of $0.5^{\circ} 2 \theta \mathrm{min}^{-1}$. $\mathrm{NaCl}$ was used as internal standard for instrumental distortion correction (position and width at half maximum height). The $\mathrm{Gt} /(\mathrm{Gt}+\mathrm{Hm})$ ratio was estimated based on the peaks area of the minerals, according to Torrent and Cabedo (1986). To quantify the Hm and Gt at the clay fraction, it was promoted the 
$\mathrm{Fe}_{2} \mathrm{O}_{3}$ content allocation obtained with DCB in these minerals considering the chemical formula, $\mathrm{Gt} /(\mathrm{Gt}+\mathrm{Hm})$ ratio and isomorphic substitution of Fe by Al (IS) (Melo et al., 2001b). The IS of Gt and $\mathrm{Hm}$ was estimated by the peaks position of these minerals (Schulze, 1984 and Schwertmann et al., 1979, respectively). The mean crystal diameter (MCD) of the Hm and Gt was calculated from the width at half maximum height (WHH) of the $\mathrm{Hm}(104)$ and (110) reflections and Gt (110), (130) and (111) reflections using the Scherrer equation (Klug and Alexander, 1954). To obtain the WHH ( $\beta$ value), the adjusted equation by Melo et al. (2001b) from the data presented by Klug and Alexander (1954) was used. The specific surface (SS) of Hm and Gt were determined using MCD values and geometric forms of these minerals (Fontes and Weed, 1991). The MCD of the Gb and Kt was calculated from the WHH of the (002) and (001) reflections, respectively, in desferrated clay sample (treated with DCB). The Kt crystallinity index was calculated from the diffractograms (XRD) of random samples, following the procedures presented by Hugues and Brown (1979).

Simultaneous differential thermal analysis (DTA) and thermogravimetric analyses (TG) of the desferrated samples were carried out using a Shimadzu DTG-60 instrument by heating a $20 \mathrm{mg}$ sample from ambient temperature to $1000{ }^{\circ} \mathrm{C}$ at 10 ${ }^{\circ} \mathrm{C} \min ^{-1}$, under $\mathrm{N}_{2}$-atmosphere. The chemical and mineralogical determination data were submitted to simple correlation analysis (Pearson), using the program SPSS for Windows 10.0, with the following significance for the $r$ values: significant at the 0.05 probability level; significant at the 0.01 probability level and; ${ }^{* * *}$, significant at the 0.001 probability level.

\section{RESULTS AND DISCUSSION}

\section{Particle-size analysis and mineralogical composition of the sand and silt fractions}

The results showed that clay was the major soil fraction for all soil horizons, ranging from 356 to $669 \mathrm{~g} \mathrm{~kg}^{-1}$ (Table 1). This predominance was expected, since the studied soils came from claystone of Guabirotuba Formation which originated, clayey to very clayey texture soils (Santos, 2002). Also, variation on clay and silt content in the Inceptisol profile was in accordance with the vertical decrease of the weathering degree, where the $\mathrm{C}$ horizon had the highest silt content. The silt content in the Oxisol samples could be considered high, since they are highly weathered horizons. According to Melo et al. (2000) this fact could be attributed to the inefficiency of the dispersion method for more weathered soils, in which the silt was mainly constituted by micro-aggregates of clay minerals with high stability, cemented by $\mathrm{Al}$ oxides.

The sand fraction samples were constituted only by quartz (Fig. 1), due to a high resistance of this mineral to weathering. The quartz presented tridimensional arrange of Si-O-Si covalent bonds (Schulze, 1989). As in the sand fraction, the silt fraction was dominated by quartz.

Extraction of amorphous $\mathrm{Fe}$ and Al oxides (ammonium oxalate - AO) and crystalline Fe oxides (dithionite-citrate-bicarbonate - DCB) in the clay fraction

The contents of amorphous $\mathrm{Fe}$ and $\mathrm{Al}$ oxides were smaller for the Oxisol than for the Inceptisol samples, and the Histosol stayed into an intermediate position (Table 2). It was also observed that for the same soil class, this increased with the deep, indicating that the soil age was not enough for these minerals crystallization. The dissolved material (AO) was constituted mainly by $\mathrm{Al}$ (Table 2), with less iron minerals participation, corroborating with results obtained by Ghidin (2003). The material extracted by AO has been shown to be highly effective on adsorption capacity, due to high specific surface and great number of superficial $\mathrm{pH}$ dependent charges (McKeaque and Day, 1966), conferring to the horizons, for example, high phosphorus fixation capacity as well as heavy metal adsorption (Wowk, 2003).

The water of the amorphous material was found under different forms: adsorbed/absorbed between 105 and $150{ }^{\circ} \mathrm{C}$ (Jackson, 1979) and in the mineral structure (crystallization and/or constitution) since the samples were dried at $105{ }^{\circ} \mathrm{C}$ before the treatment. The ferridrite, an hydrated $\mathrm{Fe}$ oxide $\left(2,5 \mathrm{Fe}_{2} \mathrm{O}_{3} \cdot 4.5 \mathrm{H}_{2} \mathrm{O}\right)$, precursor of the $\mathrm{Hm}$ (Schwertmann and Taylor, 1989), presented 17\% of structural water (Jackson, 1979). The water content of the amorphous material was calculated by the difference between the weigh sample reduction by $\mathrm{AO}$ extraction and the oxides sum $\left(\mathrm{Fe}_{2} \mathrm{O}_{3}+\mathrm{Al}_{2} \mathrm{O}_{3}\right)$ (Jackson, 1979) (Table 2). In general, the water contents of the removed material were not high, varying between 9.0 and 
$28.3 \%$ in the well-drained soils samples. Only the Histosol $\mathrm{H}$ horizon presented its water content quite higher to the other samples, evidencing a higher hydration degree of the amorphous minerals of the clay fraction.
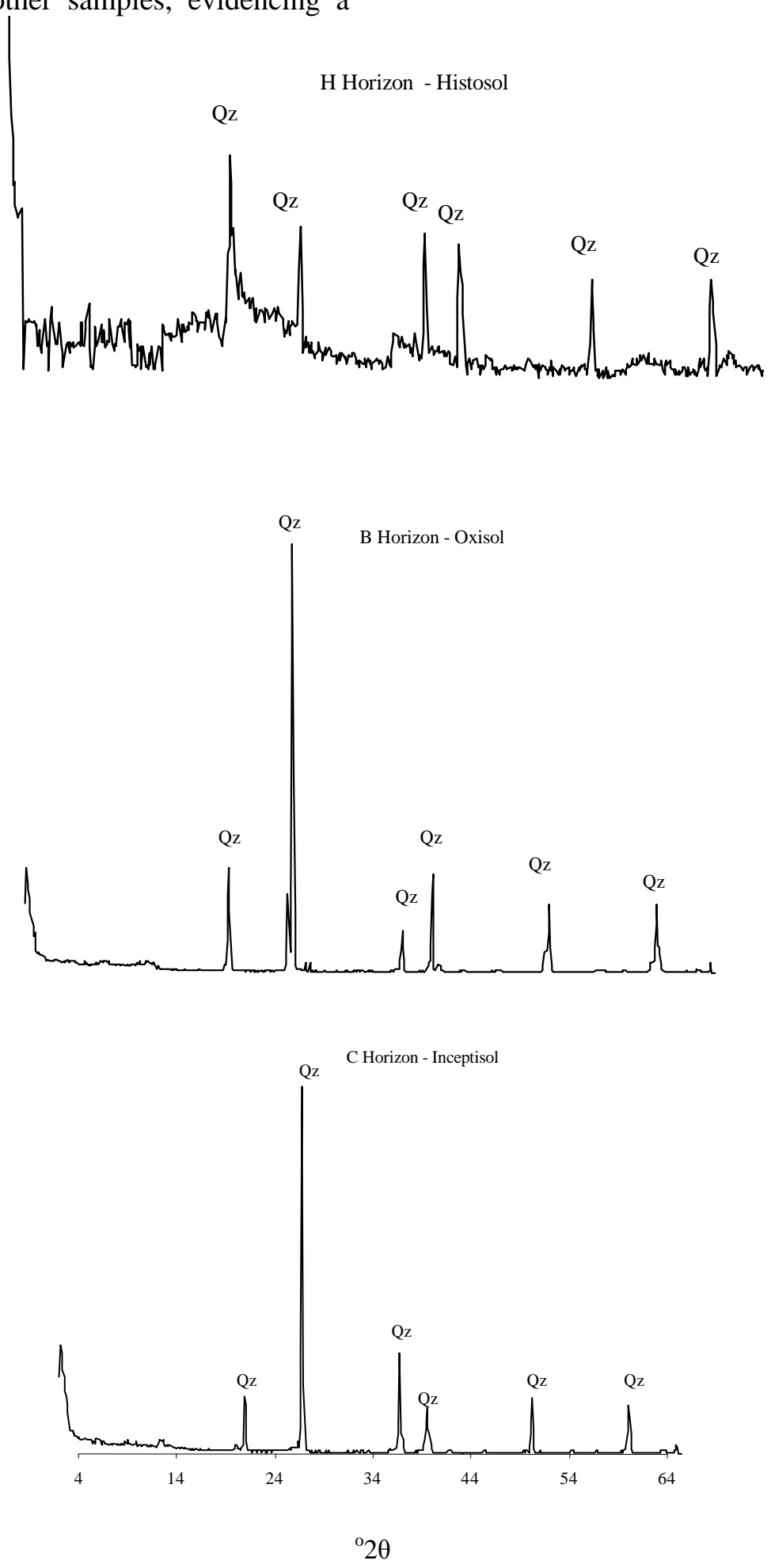

Figure 1 - X-rays difratograms of sandy random samples of the Histosol, Oxisol and Inceptisol: Qz - quartz. 
Table 2 - Contents of amorphous iron and aluminum oxides (extraction with ammonium oxalate - AO) and contents of crystalline iron oxide (extration with ditionite-citrate-bicarbonate - DCB) of the clay fraction for soils from metropolitan region of Curitiba - Parana State - Brazil

\begin{tabular}{|c|c|c|c|c|c|c|c|c|c|c|c|}
\hline \multirow{3}{*}{$\begin{array}{l}\text { Sample } \\
\text { No. }\end{array}$} & \multirow{3}{*}{$\begin{array}{c}\text { U.S. } \\
\text { Taxonomy }\end{array}$} & & \multirow{2}{*}{$\begin{array}{c}\mathrm{Fe}_{2} \mathrm{O}_{3} \\
\mathrm{OA}\end{array}$} & \multirow{2}{*}{$\begin{array}{c}\mathbf{A l}_{2} \mathbf{O}_{3} \\
\mathbf{O A}\end{array}$} & \multirow{2}{*}{ Total $^{1}$} & \multirow{2}{*}{$\begin{array}{c}\text { Weight } \\
\text { loss }^{2}\end{array}$} & \multirow{2}{*}{$\mathbf{H}_{2} \mathbf{O}^{3}$} & \multicolumn{2}{|c|}{$\begin{array}{l}\text { Oxide/ } \\
\text { total }^{4}\end{array}$} & \multirow{2}{*}{$\begin{array}{c}\mathrm{Fe}_{2} \mathrm{O}_{3} \\
\mathrm{DCB}\end{array}$} & \multirow{3}{*}{$\begin{array}{c}\mathrm{Fe}_{2} \mathrm{O}_{3} \mathrm{AO} / \\
\mathrm{Fe}_{2} \mathrm{O}_{3} \mathrm{DCB} \\
\text { RATIO }\end{array}$} \\
\hline & & & & & & & & $\mathrm{Fe}_{2} \mathrm{O}_{3}$ & $\mathrm{Al}_{2} \mathrm{O}_{3}$ & & \\
\hline & & & \multicolumn{4}{|c|}{$\mathrm{g} \mathrm{kg}^{-1}$} & \multicolumn{3}{|c|}{$\%$} & $\mathrm{~g} \mathrm{~kg}^{-1}$ & \\
\hline 1 & Histosol & $\mathrm{H}$ & 1.0 & 16.9 & 17.9 & 36.5 & 51.0 & 5.3 & 94.7 & 0.5 & 2.111 \\
\hline 2 & Oxisol & A & 1.5 & 2.3 & 3.8 & 4.2 & 9.0 & 39.8 & 60.2 & 99.0 & 0.015 \\
\hline 3 & Oxisol & Bw & 0.9 & 10.3 & 11.2 & 12.3 & 8.9 & 7.7 & 92.3 & 90.6 & 0.009 \\
\hline 4 & Inceptisol & $\mathrm{A}$ & 2.1 & 3.2 & 5.4 & 7.5 & 28.3 & 39.8 & 60.2 & 114.1 & 0.019 \\
\hline 5 & Inceptisol & $\mathrm{Bi}$ & 0.9 & 40.1 & 41.0 & 57.0 & 28.1 & 2.2 & 97.8 & 103.9 & 0.009 \\
\hline 6 & Inceptisol & $\mathrm{C}$ & 0.7 & 48.2 & 48.9 & 64.0 & 23.6 & 1.4 & 98.6 & 51.2 & 0.013 \\
\hline
\end{tabular}

${ }^{1}$ Total $=$ sum of amorphous oxides $\left(\mathrm{Fe}_{2} \mathrm{O}_{3}+\mathrm{Al}_{2} \mathrm{O}_{3}\right)$

${ }^{2}$ Weight loss = weight sample reduction by the AO treatment [(initial weight - final weight)/initial weight * 1000];

${ }^{3} \mathrm{H}_{2} \mathrm{O}=[($ weight loss $(\mathrm{AO})-$ oxides sum $) /$ weight loss $(\mathrm{AO})] \times 100$;

${ }^{4}$ Participation of $\mathrm{Fe}_{2} \mathrm{O}_{3}$ e $\mathrm{Al}_{2} \mathrm{O}_{3}$ in relation to the total (sum of oxides).

The $\mathrm{Fe}_{2} \mathrm{O}_{3}$ contents associated with the crystalline Fe oxides (DCB) ranged from 0.5 to $114.1 \mathrm{~g} \mathrm{~kg}^{-1}$ (Table 2). This amplitude was caused by the low content of crystalline Fe oxides in the Histosol, attributed to hidromorphic condition. The lowest $\mathrm{Fe}_{2} \mathrm{O}_{3}$-DCB content (low pedogenetics $\mathrm{Fe}$ oxides) of the Inceptisol $\mathrm{C}$ horizon was related to the fact that the element was still present in the primary minerals structure (low weathering degree). An evidence for this behavior was the highest silt content for this horizon (Table 1).

Except for the Histosol sample, the values found for the $\mathrm{Fe}_{2} \mathrm{O}_{3}-\mathrm{AO} / \mathrm{Fe}_{2} \mathrm{O}_{3}$-DCB ratio were very low (Table 2), indicating crystalline forms dominance. The higher organic matter (Table 1) and amorphous $\mathrm{Al}$ and $\mathrm{Fe}$ oxides contents (Table 2) were verified in the $\mathrm{H}$ horizon sample. This behavior was also observed by Melo et al. (2002). The humic fraction of the organic matter has a strong inhibitor effect on the $\mathrm{Fe}$ oxides crystallization (Schwertmann et al., 1979), favoring the reduction of this ratio with the soil deep (Table 2). These behavior was evidenced by the high correlation found between organic carbon content and $\mathrm{Fe}_{2} \mathrm{O}_{3} \mathrm{OA} / \mathrm{Fe}_{2} \mathrm{O}_{3} \mathrm{DCB}$ ratio $\left(\mathrm{r}=0.93^{* *}\right)$. Another factor that limited the $\mathrm{Fe}$ and $\mathrm{Al}$ oxides crystallization in the Histosol $\mathrm{H}$ horizon was the hidromorphic condition (Wowk, 2003).

\section{Mineralogical composition of the clay fraction}

Kaolinite (Kt) was the dominant clay mineral in all studied soils (Fig. 2), where its contents ranged from 676.7 to $820.8 \mathrm{~g} \mathrm{~kg}^{-1}$ (Table 3). Hence, even presenting lower CEC than 2:1 minerals (McBride, 1994), the kaolinite affected many important physical-chemical processes in the soils, such as, the adsorption reactions, formation and stabilization of the aggregate, water dynamics in the profile, among others.

The development process of the soils involves $\mathrm{Si}$ loss, where 2:1 minerals become instable and, through weathering, they form more equilibrated minerals with the environmental conditions, gradually with a lower $\mathrm{Si}$ concentration (Kt and gibbsite - Gb) (Hsu, 1989). Analyzing the extreme conditions, the highest $\mathrm{Gb}$ content was found on the Oxisol A horizon $\left(219.6 \mathrm{~g} \mathrm{~kg}^{-1}\right)$ and the lowest on the Inceptisol $\mathrm{C}$ horizon $\left(81.0 \mathrm{~g} \mathrm{~kg}^{-1}\right.$ ) (Table 3). The inverse relation between the $\mathrm{Si}$ and $\mathrm{Gb}$ contents in the soil was also reported by Curi and Franzmeier (1984) and Melo et al. (2001b).

The crystalline $\mathrm{Fe}$ oxides contents (hematite-Hm and goethite-Gt) was low (Table 3) when compared with soils derived from $\mathrm{Fe}$ rich parent material, as the basalt (Ghidin, 2003). The higher Gt content in relation of $\mathrm{Hm}$ in the samples could be explained by the shortage of parent material in $\mathrm{Fe}$; the complexity action of Fe by organic matter; the cold and humid climate of the region (Schwertmann and Taylor, 1989). However, a high correlation coefficient value between the $\mathrm{Hm}$ and Gt contents in the soil $\left(\mathrm{r}=0.98^{* *}\right)$ was observed, suggesting that there was an association between the crystalline $\mathrm{Fe}$ oxides formation.

The vermiculite occurrence in acid soil may originate the hydroxide-interlayered vermiculite (HIV) by Al polymerization and partial fitting of the 2:1 interlayer minerals (Harris et al., 1988). The presence of Al- hydroxide may enhance stability to the $2: 1$ minerals, making that in natural 
systems, Kt, Gb and HIV can be found together in the clay fraction of the soils (Harris et al. 1988). In the present study, the HIV formation (Table 3 and Fig. 2) was favored by the high $\mathrm{Al}$ activity on the soils horizons $\left(\mathrm{Al}^{+3}\right.$ contents varying from 0.5 to $11.7 \mathrm{cmol}_{\mathrm{c}} \mathrm{kg}^{-1}$ - Pires, 2004). The HIV occurrence, mainly in highly weathered soils is important, due to its high specific surface and CEC (Sparks, 1987). The HIV was not the only 2:1 mineral observed on the youngest horizons of the Inceptisol (Table 3). Was also observed vermiculite, in the separated phase in these samples, indicating that the pedogenetic process was not sufficient to allow the Al-hydroxide islands formation. With the treatments made in the clay fraction (Whittig and Allardice, 1986), the smectite was also observed in the B and C horizons of the Inceptsol (Fig. 2). The difference between $1000 \mathrm{~g} \mathrm{~kg}^{-1}$ and the minerals sum on the $\mathrm{C}$ horizon was $106.7 \mathrm{~g} \mathrm{~kg}^{-1}$ (Table 3). Considering that a great part of this difference could be attributed to the vermiculite and/or smectite (only qualitative analysis by XRD - Fig. 2), these confirmed the results of Massad et al. (1981), in which the high activity of these minerals was responsible by the expansion and contraction of the youngest horizons originated from claystone of the Guabirotuba Formation.

\section{X-ray diffraction (XRD) based minerals measurements}

Besides the clay fraction content (Table 1) and mineralogical composition (Table 3), the nature and crystallographic characteristics of the minerals are also important to define the physical-chemical characteristics of the soils. A high activity in the soil (higher adsorption, water retention, etc.) is related to minerals with higher specific surface (defined by size and form), superficial electric charges density and low crystallinity degree.

\section{Hematite and Goethite}

The crystallographic characteristics of the $\mathrm{Fe}$ oxides were studied by XRD in iron-concentrated clay samples (residue from the $\mathrm{Kt}$ and $\mathrm{Gb}$ extraction with $5 \mathrm{~mol} \mathrm{~L}^{-1} \mathrm{NaOH}$ ). There was a great difficulty to measure the exact position of the peaks for Gt (130) and for Hm (104) (Table 4), due to the proximity between these reflections. In addition to that, there was a limitation in the mean crystal diameter (MCD) determination for $\mathrm{Gt}$ (130) in the Inceptisol C horizon, as result of the low oxides crystallinity (initial stage of formation). The MCD for the Gt (110) and (111) and for the $\mathrm{Hm}$ (104) and (110) was similar to most of the samples (ratios between the MCD values near 1.0 Table 4), indicating the iso-dimensional form of these minerals in humid tropics (Fontes and Weed, 1991).

In the minerals, which tend to have spherical forms, like $\mathrm{Hm}$ and $\mathrm{Gt}$, the increment in their volume results into reduction of expose area per mass unit, that is, specific surface (SS) diminish. According to Curi and Franzmeier (1984) the Gt has a bigger SS, consequently a higher activity and adsorption capacity than the Hm. In general, the MCD values found for the Hm were higher than the ones verified for the Gt, what resulted, generally, into a smaller SS for the Hm (Tables 4 and 5).

The isomorphic substitution values of $\mathrm{Fe}$ by $\mathrm{Al}$ (IS) within the Gt structure varied from 70.5 to $141.9 \mathrm{mmol} \mathrm{mol}^{-1}$ (Table 5), with an average of $100.6 \mathrm{mmol} \mathrm{mol}^{-1}$. On the other hand, for the Hm, as it was expected (Schwertmann et al., 1979), the IS values were lower, staying between 6.3 and $96.2 \mathrm{mmol} \mathrm{mol}^{-1}$, with an average of $58.8 \mathrm{mmol}$ $\mathrm{mol}^{-1}$.

A high and significant correlation coefficient was observed between IS for $\mathrm{Gt}$ and $\mathrm{Hm}\left(\mathrm{r}=0.95^{* *}\right)$, demonstrating that the phenomena occured in associative way for both $\mathrm{Fe}$ oxides (the same pedo-environmental conditions for the $\mathrm{Gt}$ and $\mathrm{Hm}$ formation), corroborating with results obtained by Schwertmann and Kämpf (1985). Due to the lowest $\mathrm{Al}$ ionic ray, the unit cell size, mainly in the $\mathrm{Z}$ axis (Schwertmann and Taylor, 1989), and the mineral crystallinity degree were reduced with the IS. 


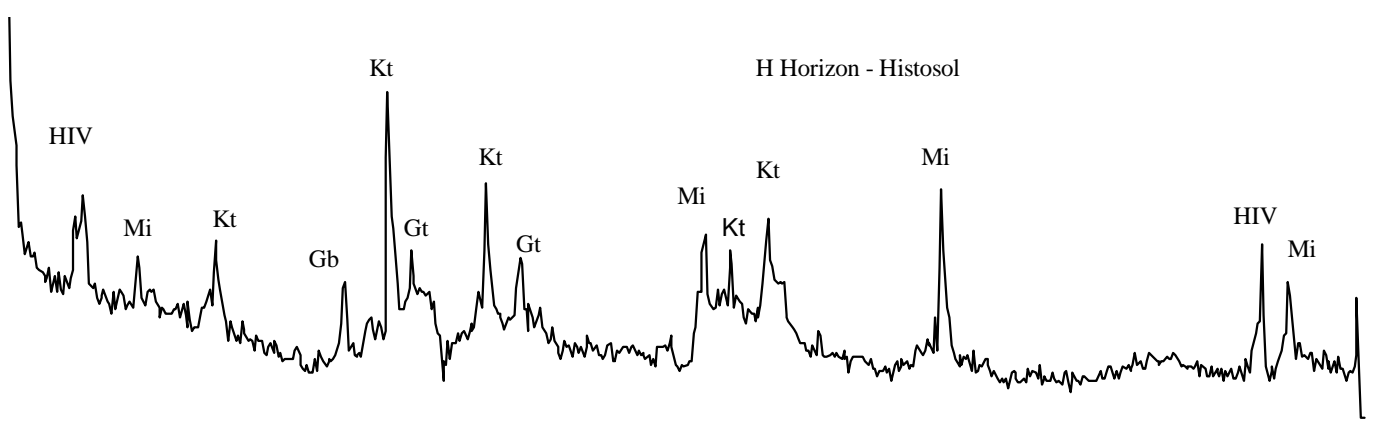

B Horizon - Oxisol
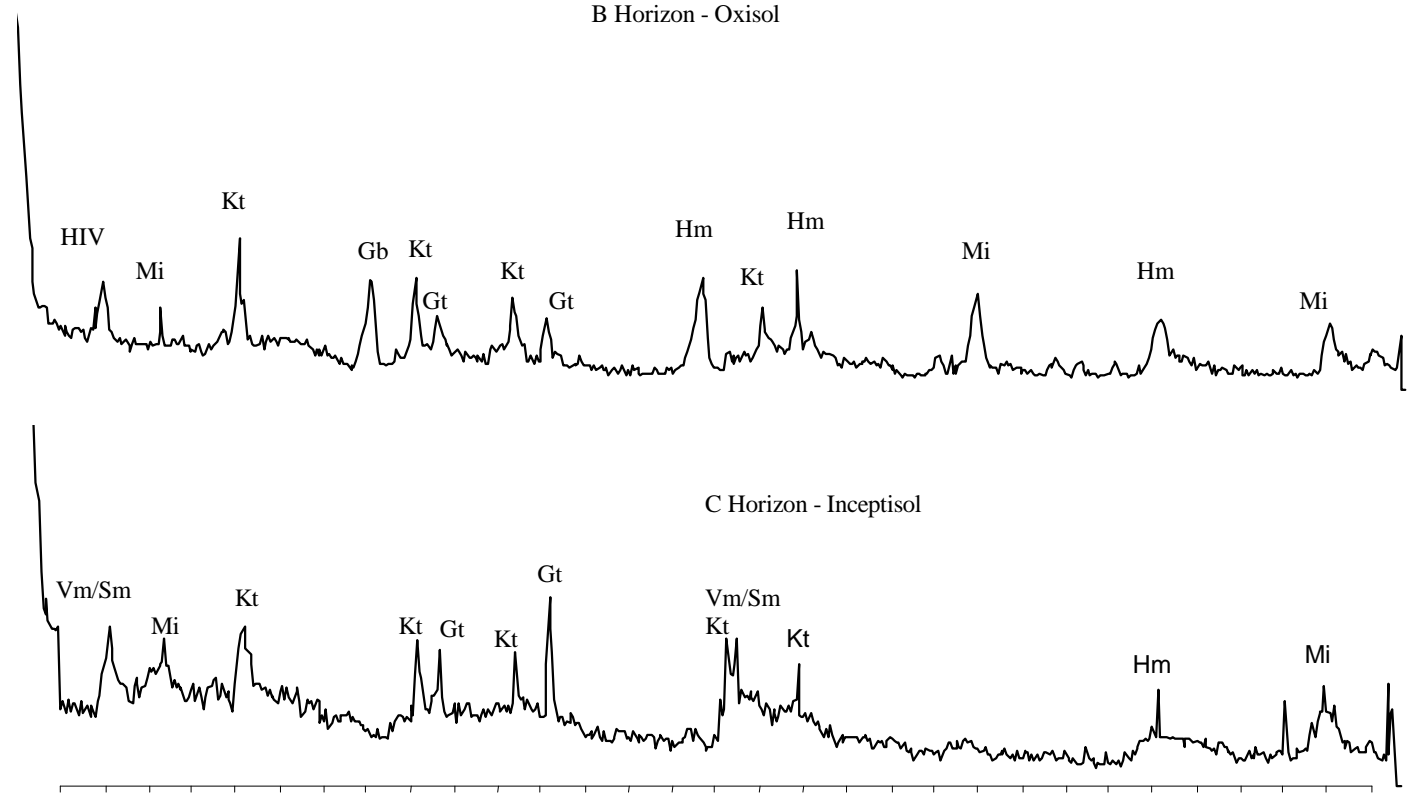

$\begin{array}{lllllllllllllllllllllllllllllll}4 & 6 & 8 & 10 & 12 & 14 & 16 & 18 & 20 & 22 & 24 & 26 & 28 & 30 & 32 & 34 & 36 & 38 & 40 & 42 & 44 & 46 & 48 & 50 & 52 & 54 & 56 & 58 & 60 & 62 & 64\end{array}$

${ }^{\mathrm{o}} 2 \theta$

Figure 2 - X-rays difratograms of clay paralell-oriented samples of the Histosol, Oxisol and Inceptisol: Qz - quartz, Kt - kaolinite, Mi - mica, HIV - hydroxy-interlayered vermiculite, Vm - vermiculite, Sm - smectite, Gb - gibbsite, Gt - goethite, $\mathrm{Hm}$ hematite.

Tale 3 - Mineralogical composition of the clay fraction for soils from metropolitan region of Curitiba - Parana State - Brazil ${ }^{1}$

\begin{tabular}{|c|c|c|c|c|c|c|c|c|c|c|c|}
\hline \multirow{2}{*}{$\begin{array}{l}\text { Sample } \\
\text { No. }\end{array}$} & \multirow{2}{*}{$\begin{array}{c}\text { U.S. } \\
\text { Taxonomy }\end{array}$} & & $\mathbf{K t}$ & Gb & Gt & $\mathbf{H m}$ & $\begin{array}{c}\text { Amorphous } \\
\text { material }\end{array}$ & Total & \multirow[t]{2}{*}{ HIV } & \multirow[t]{2}{*}{ Mica } & \multirow[t]{2}{*}{$\begin{array}{l}\text { Vermiculite/ } \\
\text { Smectite }\end{array}$} \\
\hline & & & \multicolumn{6}{|c|}{$\mathrm{g} \mathrm{kg}^{-1}$} & & & \\
\hline 1 & Histosol & $\mathrm{H}$ & 820.8 & 112.8 & 4.0 & $*$ & 36.5 & 974.1 & $\mathrm{nq}$ & $\mathrm{nq}$ & $*$ \\
\hline 2 & Oxisol & A & 661.7 & 219.6 & 75.0 & 38.0 & 4.2 & 998.5 & $\mathrm{nq}$ & $\mathrm{nq}$ & $*$ \\
\hline 3 & Oxisol & $\mathrm{Bw}$ & 671.3 & 211.5 & 68.0 & 34.0 & 12.3 & 997.1 & $\mathrm{nq}$ & $\mathrm{nq}$ & $*$ \\
\hline 4 & Inceptisol & A & 684.3 & 156.7 & 89.0 & 55.0 & 7.5 & 992.5 & $\mathrm{nq}$ & $*$ & $*$ \\
\hline 5 & Inceptisol & $\mathrm{Bi}$ & 722.5 & 85.7 & 85.0 & 37.0 & 57.0 & 987.2 & $*$ & nq & $\mathrm{nq}$ \\
\hline 6 & Inceptisol & $\mathrm{C}$ & 719.3 & 81.0 & 19.0 & 10.0 & 64.0 & 893.3 & $*$ & $\mathrm{nq}$ & $\mathrm{nq}$ \\
\hline
\end{tabular}

${ }^{1} \mathrm{Kt}$ (kaolinite) and $\mathrm{Gb}$ (Gibbsite) estimated from TGA; hematite and goethite estimated from $\mathrm{Fe}_{2} \mathrm{O}_{3}-\mathrm{DCB}$ and $\mathrm{Gt}(\mathrm{Gt}+\mathrm{Hm})$ ratio (XRD); AO, amorphous $\mathrm{Al}$ and $\mathrm{Fe}$ oxides estimeted by weight sample reduction after ammonium oxalate extraction [(initial weigth - final weigth)/initial weigth x 1000]; Total = sum of mineral contents (quantitative analysis); HIV, hydroxy-interlayered vermiculite; * mineral not-detected;. nq mineral only identified by XRD (qualitative analysis). 
To indicate the Gt crystallinity degree, the width at maximum half height (WHH) in the (111) domain was used. The lower WHH values demonstrated a higher crystallinity degree, with less presence of $\mathrm{Al}$ in the structure (lower IS) (Fitzpatrick and Schwertmann, 1982). Following the IS values, the lowest WHH of the Gt (111) was observed for the Inceptisol B and C horizons (Table 5). This way, young well-drained horizons developed from claystone of the Guabirotuba Formation (Curitiba region) presented low clay contents (Table 1), high amorphous $\mathrm{Fe}$ and $\mathrm{Al}$ oxides contents (extraction with AO - Table 2), and low crystalline Fe oxides contents (extraction with DCB - Table 2). Also, the Gt particles had low IS and high crystallinity degree (Table 5).

Among the well-drained soils, the highest $\mathrm{Gb}$ contents (Table 3) and IS values for Gt and $\mathrm{Hm}$ were detected in the $\mathrm{A}$ and $\mathrm{B}$ horizons

Table 4 - Interplanar distance (d) and mean crystal diameter (MCD) of goethite (Gt) and hematite (Hm) for the clay fraction for soils from metropolitan region of Curitiba - Parana State - Brazil ${ }^{1}$

\begin{tabular}{|c|c|c|c|c|c|c|c|c|c|c|c|c|c|}
\hline \multirow{3}{*}{$\begin{array}{l}\text { Sample } \\
\mathbf{N}^{\mathbf{0}}\end{array}$} & \multirow{3}{*}{$\begin{array}{c}\text { U.S. } \\
\text { Taxonomy }\end{array}$} & & \multicolumn{5}{|c|}{ d-corrected } & \multicolumn{4}{|c|}{ MCD } & \multirow{2}{*}{\multicolumn{2}{|c|}{ MCD Ratio ${ }^{2}$}} \\
\hline & & & $\begin{array}{c}\text { Gt } \\
(\mathbf{1 1 0})\end{array}$ & $\begin{array}{c}\text { Gt } \\
(111)\end{array}$ & $\begin{array}{c}\mathbf{G t} \\
(\mathbf{1 3 0})\end{array}$ & $\begin{array}{l}\text { Hm } \\
(104)\end{array}$ & $\begin{array}{c}\text { Hm } \\
\text { (110) }\end{array}$ & $\begin{array}{c}\text { Gt } \\
(\mathbf{1 1 0})\end{array}$ & $\begin{array}{c}\text { Gt } \\
(111)\end{array}$ & $\begin{array}{c}\text { Hm } \\
\text { (104) }\end{array}$ & $\begin{array}{c}\mathrm{Hm} \\
(\mathbf{1 1 0})\end{array}$ & & \\
\hline & & & \multicolumn{5}{|c|}{$\mathrm{nm}$} & \multicolumn{4}{|c|}{$\mathrm{nm}$} & $\mathbf{A}$ & B \\
\hline 1 & Histosol & $\mathrm{H}$ & 0.413 & 0.245 & $*$ & $*$ & $*$ & 17.4 & 23.8 & $*$ & $*$ & 0.7 & pnd \\
\hline 2 & Oxisol & A & 0.414 & 0.243 & 0.265 & 0.269 & 0.251 & 13.0 & 16.3 & 18.1 & 20.7 & 0.8 & 0.9 \\
\hline 3 & Oxisol & $\mathrm{Bw}$ & 0.415 & 0.246 & 0.266 & 0.267 & 0.252 & 35.0 & 36.0 & 47.2 & 24.4 & 1.0 & 1.9 \\
\hline 4 & Inceptisol & A & 0.419 & 0.246 & 0.266 & 0.269 & 0.252 & 10.6 & 21.2 & 21.0 & 21.1 & 0.5 & 1.0 \\
\hline 5 & Inceptisol & $\mathrm{Bi}$ & 0.419 & 0.246 & 0.267 & 0.268 & 0.252 & 16.1 & 21.2 & 12.6 & 21.0 & 0.8 & 0.8 \\
\hline 6 & Inceptisol & $\mathrm{C}$ & 0.412 & 0.244 & $*$ & 0.268 & 0.252 & 23.1 & 24.0 & 23.6 & 20.5 & 1.0 & 1.1 \\
\hline
\end{tabular}

$1 *$, mineral not-detected; pnd, mineral present but parameter not determined due to low intensity of the reflection. ${ }^{(2)}$ Ratios of the DMC values: $\mathrm{A}=\mathrm{MCD} \mathrm{Gt}(110) / \mathrm{MCD} \mathrm{Gt}(111)$ and $\mathrm{B}=\mathrm{MCD} \mathrm{Hm}(104) / \mathrm{MCD} \mathrm{Hm}(110)$.

Table 5 - Width at half maximum height (WHH), specific surface (SS) and isomorphic substitution of Fe by $\mathrm{Al}$ (IS) in goethite $(\mathrm{Gt})$ and hematite $(\mathrm{Hm})$ and $\mathrm{Gt} /(\mathrm{Gt}+\mathrm{Hm})$ ratio for the clay fraction for soils from metropolitan region of Curitiba - Parana State - Brazil ${ }^{1}$

\begin{tabular}{|c|c|c|c|c|c|c|c|c|}
\hline \multirow[t]{3}{*}{ Sample $\mathbf{N}^{\mathbf{0}}$} & \multirow{3}{*}{$\begin{array}{c}\text { U.S. } \\
\text { Taxonomy }\end{array}$} & & \multirow[t]{3}{*}{$\mathbf{G t} /(\mathbf{G t}+\mathbf{H m})$} & \multicolumn{2}{|c|}{ IS } & \multicolumn{2}{|c|}{ SS } & \multirow{2}{*}{$\begin{array}{l}\text { WHH } \\
\text { Gt (111) }\end{array}$} \\
\hline & & & & Gt & $\mathbf{H m}$ & Gt & Hm & \\
\hline & & & & \multicolumn{2}{|c|}{$\mathrm{mmol} \mathrm{mol}^{-1}$} & $\mathrm{~m}^{2}$ & & $\mathrm{O}_{2 \theta}$ \\
\hline 1 & Histosol & $\mathrm{H}$ & 1.0 & 141.9 & pnd & 78.9 & pnd & 0.35 \\
\hline 2 & Oxisol & A & 0.7 & 110.0 & 87.6 & 105.5 & 63.6 & 0.51 \\
\hline 3 & Oxisol & Bw & 0.6 & 102.2 & 96.2 & 39.2 & 41.4 & 0.23 \\
\hline 4 & Inceptisol & $\mathrm{A}$ & 0.6 & 86.4 & 55.7 & 129.5 & 59.2 & 0.34 \\
\hline 5 & Inceptisol & $\mathrm{Bi}$ & 0.7 & 82.0 & 48.3 & 85.3 & 74.7 & 0.17 \\
\hline 6 & Inceptisol & $\mathrm{C}$ & 0.7 & 70.5 & 6.3 & 59.4 & 57.6 & 0.17 \\
\hline
\end{tabular}

$1 *$, mineral not-detected; pnd, mineral present but parameter not determined due to low intensity of the reflection.

of Oxisol (Table 5). Also, the Gb formation and the IS occurrence were favored by the weathering process since there was tight relation between $\mathrm{Gb}$ content and IS in the Gt and Hm, with correlation coefficient equal to $0.94^{* * * *}$ and $0.82^{*}$, respectively. Schwertmann and Kampf (1985) and Melo et al.(2001b) found also a close and positive correlation between the same parameters.

\section{Kaolinite and gibbsite}

The $\mathrm{d}(001)$ values for $\mathrm{Kt}$ in the clay fraction varied from 0.716 to $0.728 \mathrm{~nm}$, where the lowest value was verified on the Oxisol A horizon and the highest on the Inceptisol A horizon (Table 6). It was possible that the occurrence of interstratification with 2:1 clay minerals and small crystal size influenced $d$ (001) for kaolinite (Singh and Gilkes, 1992).

The dehydroxylation temperature (DT) of the Kt, determined by thermal analysis, varied from 493 to $504^{\circ} \mathrm{C}$, with an average of $497.8^{\circ} \mathrm{C}$ (Table 6). 
This value was approximately $10^{\circ} \mathrm{C}$ superior to the one found by Singh and Gilkes (1992) for the soils developed under humid tropical conditions, but it was far below to $540^{\circ} \mathrm{C}$ obtained for $\mathrm{Kt}$ from Georgia kaolin mine. According to the same authors, the variations in the DT values could be associated with the size and degree of structural disorder of the $\mathrm{Ct}$ and experimental conditions.

The results for CI showed on the Table 6 indicated that the lowest CI was observed on the Inceptisol $\mathrm{C}$ horizon, contrasting with the Oxisol sample from upper layer (Table 6). Although the Hughes and Brown Crystallinity Index (CI) is an empirical index and provides no information about the structural defects, it is useful in ranking disordered $\mathrm{Kt}$ samples. Melo et al. (2001a) found positive and significant correlation among the weathering degree of the soil, CI, particle size (MCD) and dehydroxylation temperature for the Kt. In the present study, the correlation coefficient between $\mathrm{CI}$ and MCD for the Kt was equal to $0.81^{*}$.

The MCD (002) for the Gb varied from 9.5 to 55.7 nm (Table 7). The lowest MCD (002) value was found in the Inceptisol $C$ horizon sample, where the $\mathrm{Gb}$ was in the initial formation stages (lowest mineral content - Table 3). Opposite behavior was verified for the Oxisol samples. Hence, the highest intensity of the pedogenetic factors favored the increasing of content and particle size mineral $(\mathrm{r}$ between content and MCD of the $\mathrm{Gb}=0.84^{*}$ ). The non-significant correlation between MCD and DT for the $\mathrm{Gb}(\mathrm{r}=-0.30)$ indicated that the dehydroxylation of the mineral did not depend on the particles size, agreeing with the results obtained by Melo et al. (2001b). Comparing with the Fe oxides, the $\mathrm{Gb}$ presented, in general, a higher MCD (Tables 4 and 7), confirming results found by Melo et al. (2001b). This observation demonstrated that the $\mathrm{Fe}$ oxides had bigger adsorption capacity than the $\mathrm{Gb}$, since a lower MCD implied into a higher SS.

Table 6 - Crystallographic characteristics of the kaolinite (XRD analysis) and dehidroxilation temperature (DT) of the mineral of the soil clay fraction samples for soil from metropolitan region of Curitiba - Parana State - Brazil ${ }^{1}$

\begin{tabular}{|c|c|c|c|c|c|c|c|c|}
\hline \multirow{2}{*}{$\begin{array}{l}\text { Sample } \\
\mathbf{N}^{\mathbf{0}}\end{array}$} & \multirow{2}{*}{\multicolumn{2}{|c|}{$\begin{array}{c}\text { U.S. } \\
\text { Taxonomy }\end{array}$}} & d (001) & WHH (001) & MCD (001) & DT & \multirow{2}{*}{ ANL } & \multirow{2}{*}{ CI } \\
\hline & & & $\mathrm{nm}$ & ${ }^{\mathrm{O}} 2 \theta$ & $\mathrm{nm}$ & ${ }^{\circ} \mathrm{C}$ & & \\
\hline 1 & Histosol & $\mathrm{H}$ & 0.719 & 0.56 & 14.1 & 496 & 19.4 & 8.1 \\
\hline 2 & Oxisol & A & 0.716 & 0.43 & 18.7 & 493 & 25.6 & 12.5 \\
\hline 3 & Oxisol & $\mathrm{Bw}$ & 0.723 & 0.49 & 16.0 & 497 & 22.1 & 9.2 \\
\hline 4 & Inceptisol & A & 0.728 & 0.97 & 8.2 & 499 & 11.3 & 7.2 \\
\hline 5 & Inceptisol & $\mathrm{Bi}$ & 0.719 & 1.08 & 7.3 & 504 & 10.0 & 7.9 \\
\hline 6 & Inceptisol & $\mathrm{C}$ & 0.717 & 0.77 & 10.3 & 498 & 14.3 & 6.1 \\
\hline
\end{tabular}

Table 7 - Crystallographic characteristics of the gibbsite (XRD analysis) and dehidroxilation temperature (DT) of the mineral of the soil clay fraction samples for soils from metropolitan region of Curitiba - Parana State - Brazil ${ }^{1}$

\begin{tabular}{llccccc}
\hline $\begin{array}{l}\text { Sample } \\
\mathbf{N}^{\mathbf{0}}\end{array}$ & $\begin{array}{c}\text { U.S. } \\
\text { Taxonomy }\end{array}$ & & d (002) & $\begin{array}{c}\text { WHH } \\
(\mathbf{0 0 2})\end{array}$ & $\begin{array}{c}\text { MCD } \\
(\mathbf{0 0 2})\end{array}$ & DT \\
\cline { 4 - 7 } & Histosol & $\mathrm{H}$ & 0.483 & 0.29 & 27.7 & 274 \\
1 & Oxisol & $\mathrm{A}$ & 0.481 & 0.22 & 36.8 & 283 \\
2 & Oxisol & $\mathrm{Bw}$ & 0.484 & 0.14 & 55.7 & 285 \\
3 & Inceptisol & $\mathrm{A}$ & 0.483 & 0.43 & 18.7 & 277 \\
4 & Inceptisol & $\mathrm{Bi}$ & 0.483 & 0.29 & 27.8 & 278 \\
5 & Inceptisol & $\mathrm{C}$ & 0.483 & 0.84 & 9.5 & 291 \\
6 & & & & & \\
\hline
\end{tabular}

${ }^{(1)} \mathrm{WHH}$, width at half maximum height; MCD, mean crystal diameter; DT, dehydroxylation temperature. 


\section{CONCLUSIONS}

1. The quartz was the only mineral identified in the sand and silt fractions. The kaolinite (Kt) was the dominant clay mineral, with contents ranging from 661.7 and $820.8 \mathrm{~g} \mathrm{~kg}^{-1}$. The gibbisite $(\mathrm{Gb})$ was also an important constituent of the most weathered horizons.

2. The hematite $(\mathrm{Hm})$ and goethite $(\mathrm{Gt})$ contents of the clay fraction were low, mainly in the Histosol, due to the hidromorphic conditions. A higher content of amorphous $\mathrm{Fe}$ and $\mathrm{Al}$ oxides (extraction with ammonium oxalate - $\mathrm{AO}$ ) were obtained in the Inceptsol, favored by the lowest weathering degree of the soil.

3 . There was hydroxy-interlayered vermiculite in the highly weathered soil (Oxisol) and it was probably important for the physical-chemical processes, since the mineral presented high CEC and specific surface (SS). On the Incepitsol C horizon, high intensity reflection of vermiculite/smectite was observed, justifying the high capacity of expansion and contraction normally observed in this layer of the soil.

4. The substitution of $\mathrm{Fe}$ by $\mathrm{Al}$ (IS) in the Gt was, on average, twice as high as the Hm one. As result, the Gt presented higher SS. On the other hand, the $\mathrm{Gb}$ presented a bigger size in relation to the $\mathrm{Fe}$ oxides.

5. A good relation between pedogenetic degree and crystallographic mineral characteristics was observed: the younger well-drained horizons presented Gt with the lowest IS and the highest cristallinity degree; lowest $\mathrm{Gb}$ particle size and lowest Kt cristallinity index.

\section{RESUMO}

Devido a grande importância dos minerais, notadamente aqueles da fração argila, sobre o planejamento de uso e sobre os impactos das atividades antrópicas, estudos detalhados da composição dos solos das regiões metropolitanas são imprescindíveis. Para avaliar as características mineralógicas e químicas de solos mais representativos da Região Metropolitana de Curitiba, estado do Paraná, foram coletadas amostras das classes Organossolo, Latossolo e Cambissolo, em diferentes profundidades. As frações areia, silte e argila foram estudadas por difratometria de Raios-X (DRX) e a fração mais fina foi submetida a análise térmica e extrações químicas com oxalato de amônio (OA), ditionitocitrato-bicarbonato (DCB) e solução de $\mathrm{NaOH} 5$ mol L ${ }^{-1}$ fervente. As características cristalográficas da hematita $(\mathrm{Hm})$, goethita $(\mathrm{Gt})$, gibbsita $(\mathrm{Gb})$ e caulinita $(\mathrm{Ct})$ foram determinadas por DRX. Os resultados permitiram concluir que: (a) o quartzo foi o único mineral identificado nas frações areia e silte. Na fração argila, verificou-se o predomínio de $\mathrm{Ct}$, com teores variando de 661,7 a $820,8 \mathrm{~g} \mathrm{~kg}^{-1}$. A Gb também foi um importante constituinte dos horizontes mais intemperizados.; (b) os teores de $\mathrm{Hm}$ e Gt da fração argila foram baixos, principalmente no Organossolo. Obteve-se maior quantidade de óxidos de $\mathrm{Fe}$ e $\mathrm{Al}$ de baixa cristalinidade (extração com OA) no Cambissolo, favorecidos pelo menor grau de intemperismo; (c) a ocorrência de vermiculita com hidroxi entre camadas no solo altamente intemperizado (Latossolo), torna-se importante para os processos físico-químicos, pois o mineral apresenta alta CTC e superfície específica (SE). No horizonte $\mathrm{C}$ do Cambissolo verificou-se reflexões de alta intensidade de vermiculita/esmectita, justificando a alta capacidade de expansão e contração observada nesta camada de solo; (d) a substituição de Fe por Al na Gt foi, em média, duas vezes superior à da $\mathrm{Hm}$. Como resultado, a Gt apresentou maior SE. Já a Gb apresentou maior tamanho em relação aos óxidos de $\mathrm{Fe}$, principalmente, nos horizontes mais intemperizados (alta correlação entre teor e tamanho do mineral). Verificou-se também relação direta entre intemperismo e tamanho e cristalinidade da $\mathrm{Ct}$.

\section{REFERENCES}

Bigarella, J.J. and Salamuni, R. (1962), Caracteres texturais dos sedimentos da Bacia de Curitiba. Geologia. Boletim da UFPR. Curitiba, 7, 1-164.

Borchardt, G. (1989), Smectites. In-Mineral in soil environments, ed. J.B. Dixon. and S.B. Weed. 2 ed. Soil Science Society of America, Madison, pp. 675728.

Boszczowski, R.B. (2001), Avaliação da tensão lateral de campo de argilas sobreadensadas: ensaios de laboratório com um solo da Formação Guabirotuba. Ms Sc Thesis, Pontifícia Universidade Católica do Rio de Janeiro, Rio de Janeiro, Brasil. 
Curi, N. and Franzemeier, D.P. (1984), Toposequense of Oxisoils from the Central Plateau of Brazil. Soil Sci. Soc. Am. J., 48, 341-346.

Douglas, L.A. (1989), Vermiculites. In-Mineral in soil environments, ed. J.B. Dixon. and S.B. Weed. 2 ed. Soil Science Society of America, Madison, pp. 635674.

Empresa Brasileira de Pesquisa Agropecuária EMBRAPA (1984), Serviço Nacional de Levantamento e Conservação do Solo. Levantamento de reconhecimento dos solos do estado do Paraná. EMBRAPA/SNLCS/SUDESUL/IAPAR. Boletim Técnico n.57, Londrina.

Empresa Brasileira de Pesquisa Agropecuária EMBRAPA (1997), Serviço Nacional de Levantamento e Conservação do Solo. Manual de Métodos de Análise de Solo. EMBRAPA, Rio de Janeiro.

Empresa Brasileira de Pesquisa Agropecuária EMBRAPA (1999), Sistema brasileiro de classificação de solos. EMBRAPA, Rio de Janeiro.

Fitzpatrick, R.W. and Schwertmann, U. (1982), Alsubstituted goethite - An indicator of pedogenic and other weathering environments in South Africa. Geoderma, 27, 335-347.

Fontes, M.P.F. and Weed, S.B. (1991), Iron oxides in selected Brazilian oxisoils. I. Mineralogy. Soil Sci. Soc. Am. J., 55, 1143-1149.

Gee, G.W. and Bauder, J.W. (1986), Particle-size analysis. In-Methods of soil analysis. ed. A. KLUTE. 2 ed. American Society of Agronomy, Madison, pp. 383-412.

Ghidin, A. (2003), Toposseqüências de Latossolos originados de rochas basálticas no Paraná, Ms Sc Thesis, Universidade Federal do Paraná, Curitiba, Brasil.

Grim, R.E. (1968), Clay mineralogy. McGraw-Hill, New York.

Harris, W.G., Hollien, K.A., Yan, T.L., Bates, S.R., Acree, W.A. (1988), Nonexchangeable potassium associated with hidroxy-interlayered vermiculite from Coastal Plain Soils. Soil Sci. Soc. Am. J., 52, 14891492.

Hsu, P.H. (1989), Aluminium oxides and oxydroxides. In-Mineral in soil environments, ed. J.B. Dixon. and S.B. Weed. 2 ed. Soil Science Society of America, Madison, pp. 331-378.

Hughes, J.C. and Brown, G. (1979), A cristallinity index for soil kaolinite and its relation to parent rock, climate and soil maturity. J. Soil Sci., 30, 557-563.

Instituto de Pesquisa e Planejamento Urbano de Curitiba - IPPUC (1991), Histórico de dados do Município de Curitiba. Curitiba, Brasil.

Jackson, M.L. (1979), Soil Chemical Analysis Advanced Course. Prentice Hall, Madison.
Kämpf, N. and Schwertmann, U. (1982), Goethite and hematite in a clime-sequence in southern Brazil and their application in classification of kaolinitic soils. Geoderma, 29, 27-39.

Klug, H.P. and Alexander, L.E. (1954), X-ray diffraction procedures for polycrystalline and amorphous materials. John Wiley Sons, New York..

Kormann, A.C.M.; Nascimento, N.A. and Chameck, P.R. ed. (1999), Características geotécnicas da Formação Guabirotuba. Anais da mesa redonda. ABMS/UFPR, Curitiba, Brasil.

Maack, R. (1969), Geografia física do Estado do Paraná. CODEPAR, Curitiba, Brasil.

Massad, F.; Rocha, J.L.R. and Yassuda, A.J. (1981), Algumas características geotécnicas de solos da Formação Guabirotuba. Anais do Simpósio Brasileiro de Solos Tropicais em Engenharia. ABMS, Rio de Janeiro, pp.706-723.

McBride, M.B. (1994), Enviromental chemistry of soils. Oxford University Press, New York.

McKeague, J.A. (1978), Manual on soil sampling and methods of analysis. Society of Soil Science, Otawa.

McKeague, J.A. and Day, J.H. (1966), Dithionite and oxalate-extractable $\mathrm{Fe}$ and $\mathrm{Al}$ as aids in differentiating various classes of soils. Can. J. Soil Sci., 46, 13-22.

Mehra, O.P. and Jackson, M.L. (1960), Ironoxide removal from soils and clays by a ditionite-citrate system buffered with sodiumbicarbonate. Clays Clay Miner., 7, 317-327.

Melo, V.F.; Novais, R.F.; Fontes, M.P.F.; Schaefer, C.E.G.R. (2000), Potássio e magnésio em minerais das frações areia e silt de diferentes solos. Rev. Bras. Ci. Solo, 24, 269-284.

Melo, V.F.; Singh, B.; Shaefer, C.E.G.R.; Novais, R.F.; Fontes, M.P.F. (2001a), Chemical and mineralogical properties of kaolinite - Rich Brazilian soils. Soil Science Society American Journal, 65, 1324-1333.

Melo, V.F.; Fontes, M.P.F.; Novais, R.F.; Singh, B.; Schaefer, C.E.G.R. (2001b), Características dos óxidos de Fe e hidróxidos de $\mathrm{Al}$ de diferentes classes de solos. Rev. Bras Ci. Solo, 25, 19-32.

Melo, V.F.; Schaefer, C.E.G.R.; Novais, R.F.; Singh, B.; Fontes, M.P.F. (2002),Potassium and magnesium in clay minerals of some Brazilian soil as indicated by a sequential extraction procedure. Comm. Soil Sci. Plant An., 33: 2203-2225.

Norrish, K. and Taylor, M. (1961), The isomorphus replacement of iron by aluminium in soil goethites. Journal Soil Science, 12, 294-306.

Pavan, M.A., Bloch, M.F., Zempuski, H.C., Miyazawa, M. Zocoler, D.C. (1992), Manual de análise química do solo e controle de qualidade. Circular, IAPAR, Londrina, 76.

Pires, A.C.D. (2004), Interação de íons $\mathrm{Zn}^{+2}$ e $\mathrm{Pb}^{+2}$ com os constituintes orgânicos e minerais de solos de Curitiba, PR. Ms Sc Thesis, Universidade Federal do Paraná, Curitiba, Brasil. 
Salamuni, E. and Stellfeld, M.C. (2001), Banco de dados geológicos geo-referenciados da Bacia Sedimentar de Curitiba (PR) como base de sistema de informação geográfica (SIG). Boletim Paranaense de Geociências. UFPR, Geologia. Curitiba, 49, 21-32.

Santos, M.D. (2002), Construção com terra crua: viabilidade tecnológica e energética em habitações sociais. Ms Sc Thesis, Centro Federal de Educação Tecnológica do Paraná, Curitiba, Brasil.

Schulze, D.G. (1984), The influence of aluminium on iron oxides. VIII - unit-cell dimensions of Alsubstituted goethites and estimation of $\mathrm{Al}$ from them. Clays Clay Miner, 32, 36-44.

Schulze, D.G. (1989), An introduction to soil mineralogy. In-Mineral in soil environments, ed. J.B. Dixon. and S.B. Weed. 2 ed. Soil Science Society of America, Madison, pp 11-34.

Schwertmann, U.; Fitzpatrick, R.W.; Taylor, R.M.; Lewis, D.G. (1979), The influence of aluminium on iron oxides. Part II. Preparation and properties of Alsubstituted hematite. Clays Clay Miner., 29, 269-276.

Schwertmann, U. and Kämpf, N. (1985), Properties of goethite and hematite in kaolinitic soils of Southern and Central Brazil. Soil Sci., 139, 344-350.

Schwertmann, U. and Taylor, R.M. (1989), Iron oxides. In: Minerals in soil environments, eds. J.B. Dixon and S.B. Weed. 2 ed., Soil Science Society of America, Madison, pp. 380-427.

Singh, B. and Gilkes, R.J. (1991), Concentration of iron oxides from soil clays by $5 \mathrm{M} \mathrm{NaOH}$ treatment: The complete removal of sodalite and kaolin. Clay Miner., 26, 463-477.

Singh, B. and Gilkes, R.J. (1992), Properties of soil kaolinites from south-western Australia. J. Soil Sci., 43, 645-667.
Sparks, D.L. (1987), Potassium dynamic in soils. Springer-Vertlag,, New York.

Torrent, J. and Cabedo A. (1986), Sources of iron oxides in reddish Brown soil profiles from calcarenites in Southern Spain. Geoderma, 37, 5766.

Witthig, L.D. and Allardice, W.R. (1986), X-ray diffraction techniques. In- Methods of soil analysis. Part 1: Physical and mineralogical methods, ed. A. Klute. American Society of Agronomy, Madison, p. 331-362.

Wowk, G.I.T. (2003), Avaliação da contaminação do solo por chumbo proveniente da reciclagem de sucatas de baterias em área de várzea no município de Paula Freitas (PR). Ms Sc Thesis, Universidade Federal do Paraná, Curitiba, Brasil.

Received: September 01, 2005; Revised: August 04, 2006; Accepted: February 22, 2007. 


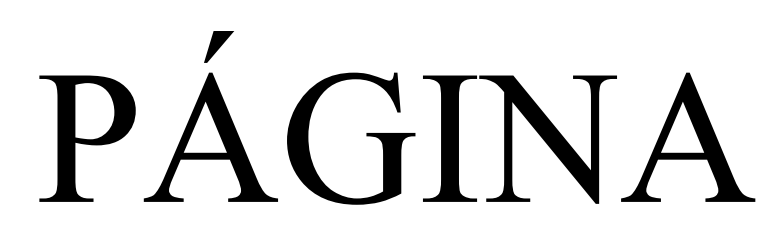

EM

BRANCO 